\title{
The Implementation of Suggestopedia Method in Arabic Teaching for Qirä'ah
}

\author{
Yogia Prihartini \\ Fakultas Tarbiyah dan Keguruan UIN Sulthan Thaha Saifuddin Jambi \\ E-mail: yogia_prihartini@uinjambi.ac.id
}

\author{
Wahyudi Buska \\ Fakultas Adab dan Humaniora UIN Sulthan Thaha Saifuddin Jambi \\ E-mail: wahyudi@uinjambi.ac.id
}

\section{Nur Hasnah}

Fakultas Tarbiyah dan Keguruan IAIN Bukit Tinggi

E-mail: hasnah_also@yahoo.com

\begin{abstract}
This research is meant to find that qirä'ah is one of important factors to see Arabic achievement as well as istimā', kaläm and kitäbah. Other factors are from the methods of teaching like: TPR (Total Physical Response), Silent way, and Community Language Learning and suggestopedia method. In this paper the writer limits the problem by focusing on teaching qirā'ah descriptive paragraph through suggestopedia method. The writer formulates the problem of this paper. The formulation is "How does the teacher teach descriptive paragraph through suggestopedia to senior high school students at State Islamic Senior High school (MAN) Model jambi". This paper is significant because it will be very useful for senior high school students, Its hoped that when the teachers apply the suggestopedia method, the students can learn qirä'ah in more enjoyable and fun environment. This paper is also important for teachers. It is hoped that they will have wider and deeper understanding of teaching methods in general, particularly suggestopedia method in teaching qirā'ah.
\end{abstract}

Keywords: Suggestopedia; Arabic Teaching; Qirä'ah.

\begin{abstract}
Abstrak: Penelitian ini dimaksudkan untuk menemukan, bahwa bacaan sebagai salah satu faktor penting untuk melihat kompetensi pembelajaran bahasa Arab selain aspek mendengar, berbicara dan menulis. Faktor-faktor lain dari keberhasilan proses pembelajaran adalah dari metode seperti: TPR (Total Physical Response), Silent way, dan Community Language Learning dan metode suggestopedia. Dalam penelitian ini penulis membatasi masalah dengan fokus pada pengajaran membaca paragraf deskriptif melalui metode sugestopedia. Penulis merumuskan masalah dari makalah ini, yaitu bagaimana guru mengajarkan paragraf deskriptif melalui sugestopedia kepada siswa Madrasah Aliyah Negeri (MAN) Model Jambi. Penelitian ini penting untuk diterapkan pada siswa Madrasah Aliyah untuk meingkatkan minat belajar bahasa Arab, Diharapkan ketika guru menerapkan metode sugestopedia, para siswa dapat belajar membaca dalam lingkungan yang lebih menyenangkan dan mengasyikkkan. Hal ini sangat penting bagi guru, karena implementasinya, mereka akan memiliki pemahaman yang lebih luas dan lebih mendalam tentang metode pengajaran secara umum, terutama metode suggestopedia dalam mengajar qirä'ah.

Kata-kata kunci: Suggestopedia; Bahasa Arab; qirā'ah.
\end{abstract}




\section{Introduction}

In Indonesia, Arabic is one of the foreign language taught in formal educational institution, formal, such as Islamic elementary school, Islamic middle school, Islamic high school, high school, and other various Islamic universities and regular universities, Arabic is also taught in non-formal educational institutions, such as Islamic boarding schools, and other various Islamic educational institutions. ${ }^{1}$

The Arabic proficiency fields include the ability to listen (listening competence/ mahärah al-Istimā'), the skill to speak (speaking competence/ mahārah al-takallum), the skill to read (reading competence/ mahārah alqirā'ah), and the skill to write (writing competence/mahaarah al kitābah) ${ }^{2}$. Arabic becomes more and more important. Qirā'ah is one of the most important skills in learning Arabic and Qirā'ah jahriyah is one of the important aspects in qirā'ah. Qirā'ah jahriyah is important because it teach students how to read a word or sentence with correct intonation and pronunciation. It is important for senior high school students read a text with bad intonation and pronunciation the listener will not understand what the students read. Even though qirā'ah jahriyah is important but now qirā'ah jahriyah is not focus in teaching qirā'ah, teacher more focus in finding main idea of paragraph, finding supporting details and asks the students to repeat after the teacher.

There are several reasons do not qirā'ah jahriyah in the class. First is based on curriculum 2013 qirā'ah jahriyah is not an aspect to teach when teacher teach qirā'ah in the classroom but focus in respond a text, identify main idea. Second is teacher doing not have enough time to give qirā'ah jahriyah because teacher should explain the aspect based on the curriculum above. Third is lack of books and media to support teacher and students to practice qirā'ah jahriyah; it is hard to find books that contain about qirā'ah jahriyah. The last is the teacher still have difficulties in applying qirā'ah jahriyah for Senior High School students in using the effective ways of qirā'ah jahriyah that they want to apply in the class because the students pay little attention and have low motivation to learn qirā'ah jahriyah because they think that learning qirā'ah jahriyah without teacher is a hard thing to do. Since qirā'ah jahriyah is not focus in teaching qirā'ah at school, some students find difficulty in doing qirā'ah jahriyah. The students cannot read with correct intonation and pronunciation when teacher asks the students to read. To help students with low qirā'ah jahriyah ability teacher give remedial teaching. In this

\footnotetext{
${ }^{1}$ Prihartini, Yogia, and Wahyudi Wahyudi. "The Development of Integrated Learning Model to Improve Language Skills at Arabic Language." IJER (Indonesian Journal of Educational Research) 3.1 (2018): 9-14.

2 Buska, Wahyudi; Prihartini, Yogia; Hasnah, Nur. Analysis of Students' Arabic Proficiency for Vocabulary Mastery in State Islamic Junior High School in Muaro Jambi. INNOVATIO: Journal for Religious Innovation Studies, 2018, 18.1: 51-62.
} 
paper, writer tries to find out how teacher give remedial teaching qirā'ah jahriyah

A proverb says that "the more you read the more you get". It means that the more you read the more information and knowledge you get. This proverb describes the importance of qirä'ah skill as one of the four skills such as kalām, istimá', and kitābah in learning language.

Qirā'ah is taught from a basic level to a high level. It is expected that the goal of teaching qirä'ah, that is to enable students to grasp information as much as possible from the paragraph, is achieved. As Nuttal (1982) says that qirā'ah does not only open students' knowledge to have a number of vocabularies, but qirā'ah also guarantees them to get the ideas of what they read. But up to the present, the students can absorb very few of them. This becomes problem to students. This paper explains about the implementation of suggestopedia method in teaching qirā'ah. ${ }^{3}$

There are some problems faced by students in grasping the message of paragraph they read. First, students are unable to understand and comprehend the paragraph. This problem occurs from students' word acquisition. They commonly have very limited vocabulary or words. When they find difficult words, they tend to ignore them and finally lead them into confusing situation in understanding qirā'ah paragraph. It makes the students feel bored to learn qirā'ah. Second, students do not know how to read well. It means they do not know the parts of paragraph, such as main idea of the paragraph, supporting ideas, read by using intonation and juncture, or practical ways to interprets or predict the meaning of words in the paragraph. Third, students do not know the grammar. Qirä'ah is not only qirā'ah word by word or just know the meaning of each word, but also a grammar a qirā'ah paragraph use. When students read Arabic paragraph and they do not know about the grammar, they will interpret the meaning of the paragraph in the wrong way, too. For these reasons, efforts to formulate a model of teaching qirā'ah comprehension are necessarily applied. In the learning process, Arabic lecturers are required to show their full potential in order to improve the individual competencies of students needed to follow advanced Arabic subjects, one of which is the most important is reading competence ${ }^{4}$.

There are four kinds qirā'ah of paragraph taught in senior high school. They are narrative paragraph, recount, anecdote, and descriptive paragraph. A narrative paragraph is a paragraph to entertain, stimulate emotion or teach the readers. It can be from real life or imagination. An anecdote is a kind of paragraph which deals with something unexpected or out of the ordinary. It usually contains some

3 Nuttal. Christine, Teaching Beading Skills in a Foreign Language. London: Merrill Publishing Company. 1982. pp. 24

${ }^{4}$ Wahyudi, Wahyudi; Prihartini, Yogia. Development of Arabic Learning Material Based on Eclectic Method. In: 3rd Asian Education Symposium (AES 2018). Atlantis Press, (2019). pp.538 
unusual or amusing incidents. A recount is a paragraph which tells events, activities, or experience happened in the past. It usually focuses on a person's past experience. A descriptive paragraph is a paragraph to describe a particular person, place or thing 5 .

One effort to teach qirä'ah comprehension is to make the students recognize the types of these paragraphs. When they know about the paragraphs, they know what grammar is used in the paragraph. They can also predict what the story is about. So, comprehending the paragraph will be easier.

Another effort to teach qirä'ah comprehension is by applying many kinds of teaching methods. As we know, there is no the exact way to teach a subject in the classroom. Teachers should vary the ways and methods. One of teaching methods to teach descriptive paragraph is by applying suggestopedia method.

From the explanation above it can be concluded that teaching method applied by teachers in the classroom can influence students comprehension in qirā'ah Arabic paragraph. It also can motivate students to read more paragraphs.

\section{The Definition of Qirā'ah}

There are some definitions of qirā'ah. Some people think that term of qirā'ah is only an activity to read word by word, phrase by phrase. sentences by sentences, or paragraph in text or passage. The other defines that is only to get the information from what they read.

Nuttal says that reading (in this article: qirā'ah) is the transfer of message from a writer to readers, specifically the transfer of meaning for mind to mind ${ }^{6}$. We have noted that the writer, the reader, and paragraph each have a unique contribution to make if communication is to take place. Then, Rosenblatt states that reading is a meaningful interpretation of the written or printed verbal symbols and that reading is an extension or oral communication?.

Also, Kirby says that reading is typical of variety of complex cognitive performance that involves a large number of discrete but independent mental processes ${ }^{8}$. It is supported by Goodman, who says that reading is a psycholinguistic guessing game that involves an interaction between though and language. He also says that reading processes are 237-243

5 Paltridge, Brian. "Genre, text type, and the language learning classroom." (1996). pp.

${ }^{6}$ Nuttal. Christine, Teaching Beading Skills in a Foreign Language. London: Merrill Publishing Company. 1982. pp. 18

${ }^{7}$ Rosenblatt, Louise M. Towards a transactional theory of reading. Journal of Reading Behavior, 1969, 1.1: 31-49.

8 Kirby, John R. "Style, strategy, and skill in reading." Learning strategies and learning styles. Springer, Boston, MA, 1988. pp.229-274. 
cycles of sampling, predicting, testing, and confirming9.

Furthermore, Schiefele says that once reading material appropriate to the level and interests of particular students has been indentified, the more of material that students read. the better and the more quickly his / her reading skill will develop. ${ }^{10}$

To sum up, Qirā'ah is a process of putting the reader in contact and communication with written idea. In order to be able to extract the meaning of the paragraph, a reader must develop his or her understanding toward the paragraph that being read is basic element for comprehension. It means that reader can comprehend well about the paragraph, it she or he has good background knowledge about information in the paragraph.

\section{The Concept of Suggestopedia}

Suggestopedia is a method of teaching language that develops by George Lozanov (1978). Suggestopedia also defines as a specific set of learning recommendations derived from suggestology. He describes that suggestopedia as a science concerned influences human beings are constantly to respond. ${ }^{11}$ According to Schuster, Suggestopedia is the method that has a somewhat mystical air about the method.12 Partially because it has few direct links with established learning or educational theory in the west, and partially because its arrange terminology and neologism. Based on the statement above suggestopedia is called a package of pseudo-scientific.

In this method, Lozanov (1978) describe as a" Science concern with the systematic study of the nonrational or nonconscious influence" that human beings are constantly responding to ${ }^{13}$. The students can imagine how the teacher told them. to be more easy to the students, in this situation teacher plays the music. Furthermore, Davis states that using of music can assist student in the liberation from discrete Micro psychotraurnata for destruction of incompatible ideas about the limits of human capabilities ${ }^{14}$.

Moreover. Quast adds that there are three functions of music in sugesstopedia ${ }^{15}$, they are:

${ }^{9}$ Goodman, Kenneth S. Reading: A psycholinguistic guessing game. In: Making Sense of Learners Making Sense of Written Language. Routledge, 2014. p. 115-124.

10 Schiefele, Ulrich. Interest, learning, and motivation. Educational psychologist, 1991, 26.3-4: 299-323.

11 Bancroft, W. Jane. The Tomatis Method and Suggestopedia: A Comparative Study. 1982.

12 Schuster, Don H. The Journal of the Society for Accelerative Learning and Teaching, Volume 10, 1985. Journal of the Society for Accelerative Learning and Teaching, 1985, 10: pp.1-4.

13 Schiffler, Ludger. Suggestopedic methods and applications. Psychology Press, 1992.

14 Davis, Niki, et al. Can quality in learning be enhanced through the use of IT? In: Using IT Effectively in Teaching and Learning. Routledge, 2004. p. 23-36.

15 Quast, Ulrike. The effect of music on acquiring vocabulary with technically gifted 
To facilities the establishment and maintenance of personal relations.

To bring about increased self-esteem through increased selfsatisfaction musical performance.

To the unique potential of rhythm to energize and bring order.

By using the music, the students will be relax, enjoy and can focus their idea. Beside that, the teacher should be trained to read dialogue in special way. For example, the precise of using voice intonation and stress.

It is given to small group, around 12 students at a time, and is intensive meeting for four hours per day for month. According to Bancroft this method consists of three parts ${ }^{16}$ :

Review

It can be done through the text material, game and plays. It may include some exercises and error correction, but does not include the use of a language pattern drill.

Presentation of New material

New Material is introduced in the form of dialogue based on familiar situations to the students. To comprehend the dialogue the students should know many vocabularies and its meaning. Bushman and Madsen (in Whittaker;1999) state that the dialogue is about 10 to 14 pages ${ }^{17}$.

Bancroft defines that suggestopedia itself divided into two parts. In the first part is the active séance, the teacher reads the dialogue while the students follow the paragraph and engage in deep rhythmic Yoga breathing. However. concentration is greatly promoted by the retention or suspension of breath ${ }^{18}$.

The second part labeled the passive or concert part the séance involves music. In the central activities, the teacher reads of the dialogue with an emotional or artistic intonation. The student can join with the teacher and he/she can felt the conditions in the abroad. He/she will be usual to listen the music, style and also the behavior of the societies.

Based on some assumptions above the writer can conclude that, as an Arabic teacher, We should really sure each part in suggestopedia method. The parts namely; review presentation of new material truly original features. In addition, truly original features have two sections. The first section is passive or concert part of the séance involves music. This parts the teacher and the students influence one each other.

students. Gifted Education International, 1999, 14.1: 12-21.

${ }^{16}$ Bancroft, W. Jane. Suggestopedia and language. 2005. pp.21

17 Whittaker, David J. Leonard James Arrington (1917-1999): A Bibliography. Journal of Mormon History, 1999, 25.2: 11-45.

${ }_{18}$ Bancroft, W. Jane. From Research and Relaxation to Combination and Creativity: American Versions of Suggestopedia. 1995. pp.29 


\section{The Nature of Teaching Qirä'ah}

Hughes (2003) defines, "teaching reading is the process of redesigning syllabus, choosing new books and conducting the class differently by the emphasis on qirā'ah materials tasks"19. Moreover, Bianchini (2007) states "teaching reading is the teachers effort to encourage students to understand and learn reading materials and display them on tests and exams or in class discussion" 20 .

Prihartini States that role of the teacher in reading classroom is to facilities qirā'ah, to raise consciousness, to build confidence, to ensure systematically. To show involvement and to demand performance. In this case, we can say that the teacher should try to get students to read and develop skills aimed at improving their ability to read 21 .

Shortly, teaching qirā'ah is the process of adapting syllabus with "schoolbooks" and applying them into the classroom differently and also teaching is a challenge because qirä'ah is so complex developmental process. Learning how to teach qirā'ah require some understanding of this complexity and in addition an understanding of effective instructional strategies.

\section{The Nature of Remedial Teaching}

In learning every student have difference individual in learning processes, there are students have high and low ability in learning, beside that every students have difference knowledge and experience between one and other. To help the students that have problem with their learning the teacher can be give remedial teaching.

Remedial teaching is not repetition of earlier teaching. Friedman views remedial teaching as a teacher effort in helping students that have problems with their learning by reviewing or looking for alternative method ${ }^{22}$. So the students can develop and fulfill the criterion of minimal score. Remedial teaching is all what teacher does to notice student's problem and what teacher should do to help students to solve the problem so the students can get good score.

Yunus also states some differences between teaching and remedial teaching ${ }^{23}$ :

${ }^{19}$ Hughes, Arthur. Testing for language teachers. Ernst Klett Sprachen, 2003.

${ }^{20}$ Bianchini, Julie A.; Cavazos, Lynnette M. Learning from students, inquiry into practice, and participation in professional communities: Beginning teachers' uneven progress toward equitable science teaching. Journal of Research in Science Teaching, 2007, 44.4: 586-612.

${ }^{21}$ Prihartini, Yogia; Jambi, Iain Sts. Giving Remedial Teaching In Teaching Reading Aloud At Senior High School. Ional Islamic Education Ceeding 2015, 142.

${ }^{22}$ Friedman, Philip, and Karen A. Friedman. "Accounting for individual differences when comparing the effectiveness of remedial language teaching methods." Applied Psycholinguistics 1.2 (1980): 151-170.

${ }^{23}$ Yunus, Muhammad, Et Al. Developing The Students'ability In Reading Through Speed Reading Technique. Journal Of English Education, 2016, 1.1: 42-50. 
Purpose;

Usual teaching focuses on total content mastery so instructional effect and nurturing-effect can reach maximally, but remedial teaching more focus on the development of content mastery so at least students can fulfill minimal score criterion they may achieve.

Strategy;

The characteristic of remedial teaching strategy is very individual and emphasize or students variety that relate with students variety that relate with students general knowledge, specific knowledge, content mastery before remedial.

Teacher should present the material in various way, it is suggested that teacher present the material from easy to more difficult, systematically. So after remedial teaching is finished. It is hoped that output of the students parallel with other students in the class.

Material;

Material used in remedial teaching is usually develop with more smaller pieces that material for usual teaching, the aim is to help students the need remedial teaching to get the idea with minimal difficulties.

\section{The Nature of Qirā'ah Jahriyah}

"Etymologically, "qirā'ah" means act of someone who reads, while "jahriyah" means (1) in a voice loud enough to be heard, not in whisper, (2) loudly, so as to be heard at a distance, Boyd, As the result, reading a loud means an activity of someone who reads loudly in order to be heard from a distance place, or being heard by others ${ }^{24}$.

Danne states that "reading aloud is the phase in which children start to learn reading that focus on practicing and recognizing as well as pronouncing sound symbol of the language; while reading they are finding out the meaning of the symbol"25.

Mohammed stated that "reading aloud can be a power unless it is done for a long time"26. It means, qirā'ah jahriyah can give many advantages especially in important improving pronunciation. Harmer also added that mixing kalām, istimā', and qirā'ah skill can enrich students with language experience, because students can get a chance to predict content, istima', qirā'ah and discuss them. Consequently the three skills: need to read jahriyah.

It can be conclude that qirā'ah jahriyah is very important, primarily

${ }^{24}$ Boyd, Karen. Teacher Read Aloud: Exploring an Educational Tradition Through a Social Practice Framework. PhD Thesis. University of Manitoba (Canada). 2014.

25 Danne, Mary C., et al. Fourth-Grade Students Reading Aloud: NAEP 2002 Special Study of Oral Reading. The Nation's Report Card. NCES 2006-469. National Center for Education Statistics, 2005.

${ }^{26}$ Mohammed, Osama Ahmed Alwasila, et al. Impact of Reading Aloud on EFL Learners in Improving Reading and Pronunciation. 2018. PhD Thesis. Sudan University of Science and Technology. 
to make students practice, know the symbol pronounce the words and find the meaning of qirā'ah materials. Shortly, qirä'ah jahriyah has proved to be away to increase students pronunciation by qirā'ah jahriyah teacher can improve, check and control students pronunciation. So, qirā'ah jahriyah should be present an all teaching sequences of qirä'ah and can used in our daily lives to transfer information.

\section{Advantages of Giving Remedial Teaching in Qirā'ah Jahriyah}

Rochman (2018) says that: there are five advantages of giving remedial teaching reading aloud 27 , they are:

- Students understand themselves, especially relate with their learning achievement, their excess, their weakness, and difficulty.

- Students can change and improve their learning style to a better way to improve their learning problem.

- Students can choose suitable learning material and learning facility to help their learning problem.

- Students can develop new attitude and habit to develop their learning ability.

- Teacher knows which students need special attention and what teaching method is better to help the students.

\section{The Role of Sugestopedia}

\section{a. The Role of the Teacher}

The primary role of the teacher is to create situations in which familiar to the learners is most suggestible and then to present linguistic material in a way most likely to encourage positive reception and retention by the learner.

Lozanov says that there are several excepted teacher behaviors that contribute to those presentations. Show absolute confidence in the method. Display fastidious conduct in manner and dress. Organize properly and strictly observe the initial stage of the teaching process, including choice and play of the music as well as punctually. Maintenance a solemn attitude toward the session. Give tests and respond tactfully in the papers. Stress global rather than analytical attitudes award material. Maintain a modest enthusiasm ${ }^{28}$.

Based on the phenomena above the writer can conclude that a teacher in teaching should create situation in which the learners is most

27 Rochman, Muhammad. The Importance of Teaching Reading: Improving Students'reading Comprehension In Efl Context Emphasized On Reading Fluency And Accuracy. Journey: Journal of English Language and Pedagogy, 2018, 1.1: 6-14.

${ }^{28}$ Lozanov, G. Suggestopedia and Outlines of Suggestopedia. New York: Gordon and Breach. 1978.pp.149 
suggestible and encourage positive reception and retention. In addition, Bancroft suggests that teacher is expected to be skilled in acting, singing, and psychotherapeutic techniques. Also, the teacher should attempt to build the students confidence in their own potential for second language acquisition ${ }^{29}$.

\section{b. The Role of the Students}

The students are volunteers and they are expecting to be committed to the class in all the activities. The students here are not too active because their brain have manipulated by the teacher. They will respond if they get order from the teacher. Then, the students must obey the role in this play, such as change the name with like British names. Besides, the students ought to trust and respect to the teacher. If the students feel secure, the learner can be more spontaneous and inhibited.

\section{c. The Importance Requirement of Suggestopedia}

We have known about the concept of the sugesstopedia, the roles of suggestopedia, there are some requirements that should be considered in suggestopedia. As follows, the teacher prepares the material or dialogue are based on situations familiar with the students, and use the first language in part one to help the students confirm that he/she indeed understood the paragraph presented in the target language. The teacher should know that the student can comprehend in the paragraph and able to create self self through comprehensible the paragraph that given

The topics of the text are designed not only to be inherent interest, but also to be of some practical value an relevant to the students needs. In learning process, the teachers try to motivate their students to be interested in learning. Moreover. In this suggestopedia method the teacher ask the students to enjoy. The teacher should know about the student need in learning process. So, she/he should make the students has high motivation. It is better for the teacher to choose the good topic to make the students to be interested in learning process.

In the filter level, the students have high fluency in qirā'ah learning process. They should understand the meaning from the context. So, the teachers have to filter the students understanding about the context. There are three points that should be known as important requirements of suggestopedia. They are comprehensible it means, the teacher and the students must know about material. Next, interesting or relevant is while the teacher gives material to the students, the teacher should consider about the topic that interest for the student. The last, filter level is how far the students can be filter the teacher instructions. By

${ }^{29}$ Bancroft, W. J. 1972. The Psychology of Suggestopedia or Learning without Stress. The Education Courier Feb 1972.pp 16-19. 
applying each part of this requirement, the teacher will be successful in using this method.

\section{Teaching Phases in Suggestopedia}

There are three phases that should be followed by the teacher in the teaching learning process. It consists of pre- teaching activities, whilstteaching activities and post- teaching activities in suggestopedia. The teachers should select the materials for the preparation in the class. Also, good lesson plan will make the teaching learning process run well.

\section{a. Pre-Teaching Activity}

Pre-teaching activity is skimming and scanning in teaching process. The teacher stimulates the student's experience or background knowledge before he/she starts the lesson. This activity consists of greeting, checks the student attendance, and gives some questions based on the topic. One of the reason teachers asks question to the students is to provoke the student's ideas.

Procedures in pre-teaching activity as follows: The teacher introduces the material to the students. The students pay attention during the teacher's explanation. If the students do not pay attention, they cannot understand what the teacher says. The teacher explains the topic through suggestopedia method. The teacher prepares some equipment needed in these activities. Like: tape recorder. Instrument music and pictures. The teacher asks the students to sit in the circle form. The teacher distributes the paragraph to the students.

\section{b. Whilst-Teaching Activity}

Whilst-teaching activity is the steps of the teacher in learning process. This activity can influence the student's knowledge and skills. It gives a message describing how something to be done through direction or instruction. Furthermore, teaching activity is a crucial part of any educational process. such as: instruction and training which influence both by the ability of the teacher and the preparation of the leaner.

The procedures in whilst- teaching activity are: At the beginning of the session, all conversation stops for a minute or two, and both the teacher and the students are istima $\bar{a}^{\prime}$ to the music from a tape-recorder. The students wait and listen to several passages in order to enter into the mood of the music. Then, the teacher reads or recite the paragraph, with his/her voice modulated in harmony with the musical phrases.

The students read the paragraph by hearing the music. Between the first and second part of the music, there are several minutes of solemn silence. In some cases, even longer pauses can be given to permit to the students to stir a little. Before the beginning of the second part of the music. 
there are again several minutes of silence and some phrases of the music are heard again before the teacher begins to read the paragraph:

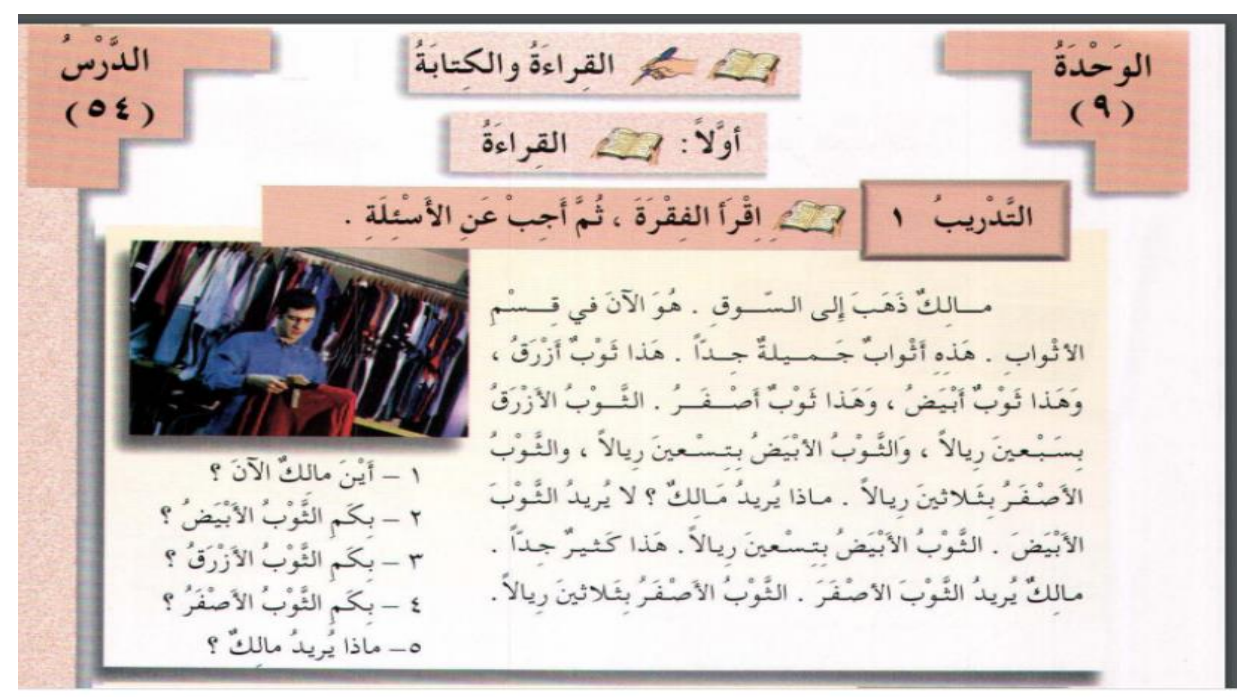

(data; quoted from textbook ${ }^{30}$ )

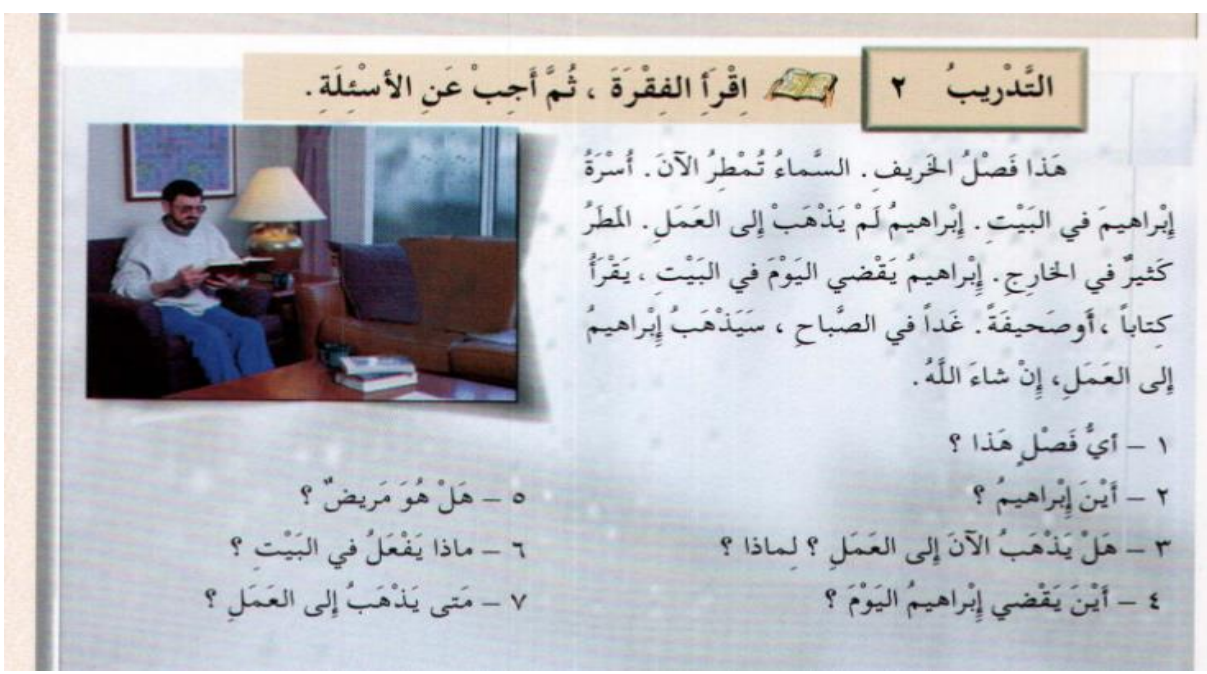

(data; quoted from textbook ${ }^{30}$ )

Now the students close their textbooks and listen to the teacher's qirā'ah. At the end, the students silently leave the room. They are not told to do their homework on the lesson they have just had except for the qirā'ah it cursorily once before going to bed and again before getting up in the morning.

30 الفوز ان، عبد الرحمن بن إبر اهيم، سلسلة في تعليم اللغة العربية لغبير الناطقبن بها:العربية بين بيليك، كتاب الطالب

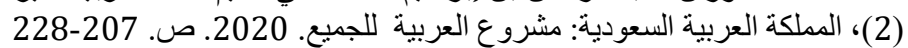




\section{c. Post-Teaching Activity}

In post-teaching activity or at the end of learning process, the teacher is the teacher gives some exercises to the students. The purpose is to know how far the students understand the lesson. Then, the teacher concludes the topic and the students are asked to do the exercises that are given by the teacher. The important thing is the teacher as a supervisor during student's activities in the classroom.

Procedures in post-teaching activity as follows:

The teacher gives opportunities for the students to ask questions if they still not understand.

The teacher gives time for a student to stand up in front of the class to read their experienced.

The teacher gives 15 minutes to do these activities

The teacher monitors them and helps if necessary. friend.

The teacher asks the students to ask some questions to his/her

The teacher reviews the lesson.

In general, the procedures of teaching-learning process are the same, they are; pre-teaching activities, whilst-teaching activities, and postteaching activities. In sugesstopedia method, the teacher should explain everything related to the material to the students (pre-teaching activity) to support their ability in the next step. During this activity, the teacher plays the music for a minute or two minutes from tape recorder. The students wait and listen to several passages of the music in the order to enter into the mood of its music.

Then, the teacher read the paragraph and asked the students to pay attention to its pronunciation, intonation and also stress. The teacher should be convinced that the students can comprehend the paragraph that has been read, and they are free and relax during this activity. While qirā'ah a paragraph. if the students get difficulties on vocabularies, they can ask the teacher.

In post-teaching activity through suggestopedia method. The students can discuss something related to the material with the teacher. The teacher gives the opportunities for the students to ask the question if they still not understand.

From-discussion above, the writer reminds the teacher of choosing an appropriate method in teaching-learning process. Suggestopedia method only used in advanced and intermediate level but it can help the students to comprehend the paragraph because; they can tell a very thing relates to the material by using their own ideas. Therefore, it's a good idea for the teacher to choose suggestopedia method in teaching-learning process to help the student in qirä'ah comprehension. 


\section{Concluding Remarks}

Based on description above, the writer can conclude as follow; there are many techniques of teaching qirä'ah some of them are using pictures, game and our experience. As Arabic teacher we are expected to be able to choose an appropriate technique. In developing student's ability in qirā'ah, teacher can use suggestopedia as a method in teaching process. Suggestopedia method is one of the ways to teach Arabic, especially in qirā'ah. There are some procedures and role of the teacher that should be followed in teaching qirā'ah through suggestopedia method.

There are some advantages of suggestopedia method, the first, to learn without stress. The second, to recognize and use your personal learning style. The third, to manage your mental and emotional states. The fourth, to use specific tools room the field of relaxation, brain Gym, mind mapping. memory enhancement, effective communication, multiply intelligence and emotional intelligence. The fifth, with the help of a skilled trainer, you will reach an open and confident attitude conducive to enhanced receptive.

Based on conclusion above, the writer would like to give several suggestions as the following: The student's level should be considered in selecting material, vocabularies, if the lexical items are too difficult for the students, they are useless. The teacher should motivate students, and encouraged them to be interested in qirä'ah. The writer would like to suggest to use suggestopedia technique in order to improve student's ability in qirā'ah In order to be effective and success in learning teaching process. 


\section{BIBLIOGRAPHY}

Bancroft, W. Jane. From Research and Relaxation to Combination and Creativity: American Versions of Suggestopedia. 1995

Bancroft, W. Jane. Suggestopedia and language. 2005.

Bancroft, W. Jane. The Tomatis Method and Suggestopedia: A Comparative Study. 1982.

Bancroft, W. Jane. The Psychology of Suggestopedia or Learning without Stress. The Education Courier Feb 1972

Bianchini, Julie A.; Cavazos, Lynnette M. Learning from students, inquiry into practice, and participation in professional communities: Beginning teachers' uneven progress toward equitable science teaching. Journal of Research in Science Teaching, 2007, 44.4: 586-612.

Boyd, Karen. Teacher Read Aloud: Exploring an Educational Tradition Through a Social Practice Framework. PhD Thesis. University of Manitoba (Canada). 2014.

Buska, Wahyudi; Prihartini, Yogia; Hasnah, Nur. Analysis of Students' Arabic Proficiency for Vocabulary Mastery in State Islamic Junior High School in Muaro Jambi. INNOVATIO: Journal for Religious Innovation Studies, 2018, 18.1: 51-62.

Danne, Mary C., et al. Fourth-Grade Students Reading Aloud: NAEP 2002 Special Study of Oral Reading. The Nation's Report Card. NCES 2006469. National Center for Education Statistics, 2005.

Davis, Niki, et al. Can quality in learning be enhanced through the use of IT? In: Using IT Effectively in Teaching and Learning. Routledge, 2004.

Friedman, Philip, and Karen A. Friedman. Accounting for individual differences when comparing the effectiveness of remedial language teaching methods. Applied Psycholinguistics 1.2 (1980): 151-170.

Goodman, Kenneth S. Reading: A psycholinguistic guessing game. In: Making Sense of Learners Making Sense of Written Language. Routledge, 2014.

Hughes, Arthur. Testing for language teachers. Ernst Klett Sprachen, 2003.

Kirby, John R. "Style, strategy, and skill in reading." Learning strategies and learning styles. Springer, Boston, MA, 1988.

Lozanov, G. Suggestopedia and Outlines of Suggestopedia. New York: Gordon and Breach. 1978.

Mohammed, Osama Ahmed Alwasila, et al. Impact of Reading Aloud on EFL Learners in Improving Reading and Pronunciation. 2018. PhD Thesis. Sudan University of Science and Technology.

Nuttal. Christine, Teaching Beading Skills in a Foreign Language. London: Merrill Publishing Company. 1982. pp. 24

Paltridge, Brian. "Genre, text type, and the language learning classroom." (1996). pp. 237-243.

Quast, Ulrike. The effect of music on acquiring vocabulary with technically gifted students. Gifted Education International, 1999, 14.1: 12-21.

Rosenblatt, Louise M. Towards a transactional theory of reading. Journal of 
Reading Behavior, 1969, 1.1: 31-49.

Rochman, Muhammad. The Importance of Teaching Reading: Improving Students'reading Comprehension In Efl Context Emphasized On Reading Fluency And Accuracy. Journey: Journal of English Language and Pedagogy, 2018, 1.1: 6-14.

Schiefele, Ulrich. Interest, learning, and motivation. Educational psychologist, 1991, 26.3-4: 299-323.

Schiffler, Ludger. Suggestopedic methods and applications. Psychology Press, 1992

Schuster, Don H. The Journal of the Society for Accelerative Learning and Teaching, Volume 10, 1985. Journal of the Society for Accelerative Learning and Teaching, 1985

Wahyudi, Wahyudi; Prihartini, Yogia. Development of Arabic Learning Material Based on Eclectic Method. In: 3rd Asian Education Symposium (AES 2018). Atlantis Press. 2019

Whittaker, David J. Leonard James Arrington (1917-1999): A Bibliography. Journal of Mormon History, 1999, 25.2

Prihartini, Yogia; Jambi, Iain Sts. Giving Remedial Teaching In Teaching Reading Aloud At Senior High School. Ional Islamic Education Ceeding 2015, 142.

Prihartini, Yogia, and Wahyudi Wahyudi. "The Development of Integrated Learning Model To Improve Language Skills at Arabic Language." IJER (Indonesian Journal of Educational Research) 3.1 (2018): 9-14.

Yunus, Muhammad, Et Al. Developing The Students'ability In Reading Through Speed Reading Technique. Journal Of English Education, 2016, 1.1: 4250.

الفوزان، عبد الرحمن بن إبراهيم، سلسلة في تعليم اللغة العربية لغبير الناطقين بها:العربية بين

بيك، كتاب الطالب (2)، المملكة العربية السعودية: مشروع العربية للجميع. 2020. ص. لإنـ 207-228 